\title{
Tax Consequences of Rescission: The Interplay Between Private and Public Law
}

When the purchaser of a tax shelter security has taken tax deductions generated by the investment, and the seller or purchaser subsequently sues for rescission, the question arises whether the income tax benefits gained by the purchaser should be considered in measuring the seller's liability to the purchaser. Under both statutory ${ }^{1}$ and common law, ${ }^{2}$ the parties to a rescission must each restore the consideration received from the other; the seller must tender the purchase price plus interest and the purchaser must tender the security plus any income gained thereon. The question concerning treatment of tax benefits arises when the seller claims that the right to receive tax benefits was part of the consideration given to the purchaser and that therefore the tax benefits-a form of "income" - should be returned to the seller.

A simple rescission hypothetical will illustrate the issue. A taxpayer in the 50 percent tax bracket invests $\$ 10,000$ in a limited partnership share in an oil drilling venture in 1973. Assuming that the only partnership item allocated to the taxpayer in that year is his proportionate share of intangible drilling and deductible development costs ${ }^{4}$ in the amount of $\$ 8,000$, the investment will yield a $\$ 4,000$ reduction in his personal income tax liability. By 1975 , after the taxpayer recognizes that the drilling venture is unsuccessful, he discovers that the seller failed to comply with the registration requirements of the federal securities laws, ${ }^{5}$ thus entitling him to res-

1 See note 6 infra.

2 See note 37 infra.

3 The issue is whether tax benefits constitute "income" for purposes of the Securities Act of 1933, $\S 12(2), 15$ U.S.C. $\S 77($ e) (1970). See note 6 infra.

4 InT. Rev. Code of 1954, § 263(c); Treas. Reg. $\S 1.612-4$ (1965). The option to deduct such expenditures currently instead of capitalizing them represents a tax benefit greater than the normally allowable deduction for business-related expenditures. Moreover, the taxpayer is entitled to deduct his proportionate share of intangible drilling and development costs which have been firmly contracted for in 1973 even though the drilling and development may not be performed until subsequent years. Rev. Rul. 71-252, 1971-1 Cum. Bull. 146.

Although in this hypothetical the limited partner has received only the intangible drilling deduction, his proportionate share of partnership losses would also include all depreciation, credits, and interest deductions. Under INT. Rev. CoDE of 1954, $\S 704$, the partnership agreement, absent a principal purpose to avoid or evade income taxes, controls the allocation of gain or loss among the partners. See id. $\$ 704(\mathrm{~b})(2)$.

5 Securities Act of $1933, \S 5,15$ U.S.C. $§ 77$ (e) (1970). The broad definition of security in the 1933 Act includes interests in oil ventures. 


\section{cind. ${ }^{6}$ Accordingly, he tenders the security and all income received thereon, which he claims amounts to zero, and demands the return of his purchase price of $\$ 10,000 .^{7}$}

The term "security" means any note, stock, treasury stock, bond, debenture, evidence of indebtedness . . . transferable share, investment contract, voting-trust certificate, certificate of deposit for a security, fractional undivided interest in oil, gas, or other mineral rights, or, in general, any interest or instrument commonly known as a "security."

Securities Act of 1933, § 2(1), 15 U.S.C. $\S 77(b)(1)(1970)$.

Most public syndications of tax shelter investments have been organized as limited partnerships. See Anderson, Tax Shelter-Going Public, U. So. Cal. 1974 Tax Inst. 595. But interests in oil ventures structured in other ways also come within the definition of "security." See, e.g., SEC v. C.M. Joiner Leasing Corp., 320 U.S. 344 (1943) (holding that assignments of oil and gas leases were "investment contracts" and hence "securities"); SEC v. Crude Oil Corp., 93 F.2d 844 (7th Cir. 1937) (holding that an interest in oil royalties sold as a bill of sale for a specified number of barrels of oil was a "security" for purposes of the federal securities laws).

"Securities" used to finance oil and gas exploration and development need not be publicly offered. See Gottesman \& Eixsenstat, Use of Limited Partnerships to Finance Drilling Ventures-Enter Rule 146, 23 OtL \& GAS TAX Q. 1 (1974). If limited partnerships come within the "private placement" exemption from the registration requirement of the Securities Act of $1933, \S 4(2), 15$ U.S.C. $\$ 77$ (d) (1970), one ground for rescission is eliminated.

- If the purchaser's ground for rescission is the vendor's failure to comply with the registration or prospectus requirements of the federal securities law, or any material misrepresentation in oral communication, he may sue for rescission under the Securities Act of 1933.

[The seller] shall be liable to the person purchasing such security from him, who may sue either at law or in equity in any court of competent jurisdiction, to recover the consideration paid for such security with interest thereon, less the amount of any income received thereon, upon the tender of security, or for damages if he no longer owns the security.

Securities Act of $1933, \S 12,15$ U.S.C. $\$ 77(1)$ (1970). If the buyer has sold the security, he may obtain damages under section 12 of the 1933 Act, 15 U.S.C. $\$ 77(1)$ (1970). Such damages "are to be measured so as to result in the substantial equivalent of rescission." 3 Loss at 1721.

Alternatively, the purchaser may sue under section 10 of the Securities Exchange Act of 1934 , 15 U.S.C. $\$ 78(j)$ (1970), and SEC Rule 10b-5, 17 C.F.R. $\S 240,10$ b-5 (1973). These remedies are available regardless of whether the purchaser still owns the security at the time of suit. See generally 3 A. Bromberg, Securities Law: Fraud, SEC Rule 10b-5, $\$ 9.1$ (1971) [hereinafter cited as BROMBERG]. Under Rule 10b-5, the plaintiff is not limited to a rescissionary measure of damages, but may elect the benefit of the bargain. "[O]ne of the advantages of the fact that his remedy under Rule $10 \mathrm{~b}-5$ is implied is that there is nothing to restrict him to a rescission measure of damages as seems to be the case on the face of $\S 12$ of the 1933 Act." 3 Loss at 1794. But the law on Rule 10b-5 damages remains unsettled. See Note, The Measure of Damages in Rule 10b-5 Cases Involving Actively Traded Securities, 26 STAN. L. Rev. 371 (1974); Note, Measurement of Damages in Private Actions Under Rule 10b-5, 1968 WASH. U.L.Q. 165, 179. Nevertheless, buyers who sue successfully under 10b-5 "have typically recovered their purchase price on a rescission measure of damages, whether or not formally suing for rescission." 3 BROMBERG, supra, $\$ 9.1$, at 226, quoted in Wolf v. Frank, 477 F.2d 467, 478 (5th Cir. 1973).

' If the taxpayer's $\$ 8,000$ share of the partnership expenditure, or a portion thereof, represents an investment in addition to the purchase price, he will also be entitled to a return of this amount from the vendor. See, e.g., Cross v. Pasley, 270 F.2d 88 (8th Cir. 1959), cert. denied, 362 U.S. 902 (1960), where expenditures in addition to the purchase price of an 
If the rescission goes forward in this form, the seller will bear the burden of the unsuccessful speculative investment but will be unable to reclaim the tax benefits that were created to encourage such investments. ${ }^{8}$ This result is contrary to the underlying theory of rescission-that the parties be returned to the status quo ante, or the relative positions they would have occupied if no such contract had been made. ${ }^{9}$ To return both parties to the status quo ante, the tax benefits would have to be returned to the seller. But the only opinions addressing the subject suggest that these benefits should be ignored in rescission. ${ }^{10}$ Moreover, a court should hesitate to deal with the problem as a strictly private law matter, for any decision ordering restoration of the tax benefits to the seller will affect the tax revenues available to the Government. Any solution to the question of treatment of tax benefits thus involves an interplay between private law remedies and public tax law.

This comment reexamines the treatment of tax benefits in rescission. It first addresses the question of allocation of the tax benefits, concluding that as a matter of private law the seller has a strong claim to recovery of the tax benefits, like profits of any other kind earned by the purchaser on the security. The comment then evaluates alternative methods of satisfying the seller's claim, either by contractual remedy or through the tax system, in light of the interplay between private and public law. A simple formula for calculating an offset to the seller's liability is suggested. Finally, the comment concludes that the seller's claim is properly handled as a mat-

interest in oil leases were held recoverable in a rescission suit as consideration for an "investment contract" and thus within the definition of "security" in the applicable state Blue Sky law. See also Whittaker v. Wall, 226 F.2d 868, 872 (8th Cir. 1955), where the court awarded restitution of the amount paid for an interest in oil and gas leases plus amounts paid for drilling expenses because the latter sums had been paid for the purpose of rendering more valuable the primary securities and were thus an integral part of the entire transaction. If the vendor is entitled to an offset for the purchaser's tax benefits, the offset would merely be deducted from this entire "repurchase" price.

8 See INT. Rev. Code of 1954, § 263(c); H.R. Con. Res. 50, 79th Cong., 1st Sess. (1945); 91 Cong. Rec. 7891-93 (1945).

See, e.g., the general definition of rescission quoted in May v. Rice, 118 F. Supp. 331, 334 (S.D. Cal. 1954), aff'd, 231 F.2d 389 (9th Cir. 1956):

Rescission means not only the annulment or abrogation of the contract, but the placing of the parties in statu quo. It implies restoration to the same situation and the same terms as existed when the contract was made, and requires the surrender of any consideration or advantage secured by either party, or an offer to restore anything received under the contract. (Citations omitted).

10 See Cooper v. Hallgarten \& Co., 34 F.R.D. 482 (S.D.N.Y. 1964); Wiesenberger v. W.E. Hutton \& Co., 35 F.R.D. 556 (S.D.N.Y. 1964). See generally 6 L. Loss, SEcuRITIEs Regulation 3921 (Supp. 1969) [hereinafter cited as Loss]. 
ter of public law by the Internal Revenue Service, rather than through a private contractual remedy.

I. The Case for Return of the Tax Benefits to the Seller

The only cases dealing with restitution of tax benefits following rescission of the sale of tax shelter securities, Cooper $v$. Hallgarten $\&$ Co. ${ }^{11}$ and Wiesenberger v. W.E. Hutton $\&$ Co., ${ }^{12}$ ruled that such benefits should not enter into the determination of the appropriate remedies. ${ }^{13}$ In those cases, the courts denied the seller's claim for an offset for the purchaser's tax benefits, and they generally offered four reasons for that result. First, in similar cases, courts had refused to consider tax benefits. ${ }^{14}$ Second, it would be an injustice to reduce plaintiff purchaser's damages "for extraneous reasons wholly unconnected with the acts of defendants." 15 Third, the sums recovered would be subject to tax treatment related to the earlier deductions and allowances. ${ }^{16}$ And, fourth, it would be unjust to return less to the high bracket purchaser than the low bracket purchaser. ${ }^{17}$ In the sections that follow, it is argued that courts, by relying on these reasons, have improperly characterized the role played by tax benefits in private contractual arrangements. It is also argued that the taxpayer has a strong private law claim to recover the purchaser's tax benefits under the principles of rescission.

\section{A. Reexamination of the Courts' Rationale}

1. Treatment of Tax Consequences in Related Situations. An examination of the related cases relied on in Cooper and Wiesenberg-awards for loss of future earnings and lump sum awards for damages spread over several previous years-indicates that the reasons for denying awards of tax benefits in those situations are inapplicable to the case of tax shelter rescission.

When compensating for loss of future earnings, a general rule has evolved that the award should not be reduced by the income taxes plaintiff would have paid on those earnings. ${ }^{18}$ Courts justify

" 34 F.R.D. 482 (S.D.N.Y. 1964).

1235 F.R.D. 556 (S.D.N.Y. 1964).

${ }^{13}$ Id. at 558; 34 F.R.D. at 485-86; 6 Loss 3921 (Supp. 1968).

1435 F.R.D. at 558; 34 F.R.D. at 486.

1535 F.R.D. at 558.

16 34 F.R.D. at 486.

17 Id.

1* Cases of this sort considered "kindred matters" by the Cooper court include McWeeney v. New York, N.H. \& H.R.R., 282 F.2d 34 (2d Cir.), cert. denied, 364 U.S. 870 (1960); and Stokes v. United States, 144 F.2d 82 (2d Cir. 1944); see Nordstrom, Income Taxes and Personal Injury Awards, 19 Oнiо ST. L.J. 212, 219 (1958). See generally Kalven, The Jury, 
the rule on the ground that plaintiff's future tax situation is speculative, varying according to his future family status, changes in the deduction and exemption provisions of the Internal Revenue Code, and changes in tax rates, ${ }^{19}$ and on the ground that the tax matters are collateral to the defendant, concerning only the plaintiff and the Government. ${ }^{20}$

Another line of cases relied upon in Cooper holds that a patentee, in an infringement suit for royalties, cannot recover the additional income tax he will have to pay because he received payment in a lump sum rather than spread over several years. ${ }^{21}$ Similarly, in actions for breach of employment contracts, lump sum damages awarded for loss of a monthly salary spread over several years are not adjusted to compensate for the additional tax expenses created by the higher marginal rate of taxation. ${ }^{22}$ The courts reason in both types of cases ${ }^{23}$ that the determination of future taxes would be too speculative ${ }^{24}$ and that tax effects are not a consequential damage flowing from the breach, ${ }^{25}$ but merely an incidental expense that is a matter between the Government and plaintiff.

That reasoning is inapplicable to the case of rescission of the sale of tax shelter securities. The tax consequences that benefit the purchaser are in no sense speculative or contingent on future events, but may be calculated at the time of rescission. The taxpayer in the rescission hypothetical, for example, gained $\$ 4,000$ in tax benefits

the Law, and the Personal Injury Damage Award, 19 OHro ST. L.J. 158, 162-63 (1958).

19 See McWeeney v. New York, N.H. \& H.R.R., 282 F.2d 34, 36-39 (2d Cir.), cert. denied, 364 U.S. 870 (1960); Nordstrom, supra note 18, at 226-27.

${ }^{20}$ See Hall v. Chicago \& N.W. Ry., 5 Ill. 2d 135, 151-52, 125 N.E.2d 77, 86 (1955); Nordstrom, supra note 18 , at $220-22$.

21 Paris v. Remington Rand, Inc., 101 F.2d 64, 68 (2d Cir. 1939).

22 McLaughlin v. Union-Leader Corp., 100 N.H. 367, 127 A.2d 269, 63 A.L.R.2d 1425 (1956), cert. denied, 353 U.S. 909 (1957).

${ }^{23}$ Another line of cases in which tax consequences are usually ignored in measuring damages arises after a profitable parent corporation files a consolidated tax return with a subsidiary that is consistently in a tax loss position. The conceptual problem is measuring the value of a tax loss to a subsidiary that may never have sufficient taxable income to use that loss, or alternatively, measuring the market value of the right to use that tax loss as an offset. See, e.g., Western Pacific R.R. Corp. v. Western Pacific R.R. Co., 345 U.S. 247, on remand, 206 F.2d 495 (9th Cir.), cert. denied, 346 U.S. 910 (1953); cf. Case v. New York Cent. R.R., 19 App. Div. 2d 383, 243 N.Y.S.2d 620, rev'd, 15 N.Y.2d 150, 256 N.Y.S.2d 607, 204 N.E.2d 643 (1965) (shareholders of a subsidiary brought a derivative suit against the parent for restitution of the difference between the tax benefits the parent received under an agreement to file consolidated returns and those it would have kept under a consolidated return absent an allegedly injurious allocation of the tax savings that had been included in the original agreement), noted in 77 HARv. L. REv. 1142, 1144-45 (1964).

${ }^{24}$ See, e.g., Paris v. Remington Rand, Inc., 101 F.2d 64, 68 (2d Cir. 1939).

${ }^{25}$ See, e.g., McLaughlin v. Union-Leader Corp., 100 N.H. 367, 370-72, 127 A.2d 269, 27273 (1956), cert. denied, 353 U.S. 909 (1957). 
from his $\$ 8,000$ deduction. The tax benefit to the purchaser at the time of rescission may thus be precisely determined although, the ultimate worth of the tax benefits after the purchaser pays taxes in the year of the rescission may be more difficult to calculate.

2. The Tax Consequences are not Collateral. Under the "collateral source" rationale, a court will refuse to reduce a defendant's liability by the amount of tax benefits awarded the plaintiff when those tax benefits are "unconnected" to the defendant's actions. In Cereal Byproducts Co. v. Hall, ${ }^{26}$ for example, the court refused to reduce the defendant's liability by an amount equal to the tax benefits awarded the plaintiff. In that case, defendant accountants had been negligent in discovering an embezzlement of their client, who sued the accountants for damages resulting from the embezzlement. Since the loss caused plaintiff by the embezzlement was reflected in its tax returns in the form of a tax refund owed plaintiff by the Government, the defendant argued that the tax refund should mitigate any damage award. But the court viewed the tax refund as a circumstance unrelated to the contractual relationship between plaintiff and its accountant and denied an offset, reasoning that "whether the plaintiff has received a tax refund on account of its loss is a matter that concerns only the plaintiff and the government." ${ }^{27}$

By contrast, the tax consequences in a transaction between the seller and purchaser of a tax shelter security are at the heart of the bargain. Anticipated tax benefits are at least as much the object of the transaction between the parties as the anticipated flow of profits. ${ }^{28} \mathrm{~A}$ common objective in tax shelter investment is to produce current deductions for which there are no current out of pocket expenditures beyond the original investment; the deductions in excess of expenditures figure prominently in the investor's

26 16 Ill. App. 2d 79, 147 N.E.2d 383 (1st Dist.), aff'd, 15 Ill. 2d 313, 155 N.E.2d 14 (1958).

27 16 Ill. App. 2 d at 81,147 N.E.2d at 384.

2* The phrase "buying and selling" tax shelters conveys the extent to which tax benefits are of the essence of the bargain. One commentator has noted that "buying' and 'selling' tax attributes . . . has become a widespread, publicly flaunted business, the objectives of which are 'profits'. . . ." Silverstein, Federal Tax Policy for Tax Shelters, 26 NaT'L Tax J. 347 (1973). One of the most effective vehicles for tax shelter is the limited partnership, which acts as a conduit for tax benefits in the form of losses, credits, and deductions. INT. REv. CODE of 1954, $\S \S 701-02$. The partnership may, within statutory limits, provide for special allocation of losses to the limited partners. See Kaster, Real Estate Limited Partnership: Special Tax Allocations, N.Y.U. 31st INST. on FED. TAX. 1799 (1973); Machtinger, New Attacks on Tax Shelters by the Courts, the Administration, and the Internal Revenue Service, U. So. CAL. 1974 TAX INST. 623, 653. Moreover, the tax basis of a limited partner may be increased by his share of partnership liabilities through non-recourse loans. INT. REv. CODE OF 1954, $\S$ 752. But cf. Rev. Rul. 72-135, 1972-1 CuM. Bull. 200; Machtinger, supra at 635-37. 
calculations concerning the ultimate profitability of the investment. If at the time of rescission an investment has generated a net tax loss, the rescinding investor under Cooper and Wiesenberger will recover the initial investment and actual losses while temporarily retaining a major part of the consideration for which he had invested. Although the purchaser will subsequently be taxed on this gain, ${ }^{29}$ the seller will bear the burden of the risk of the investment without benefiting from the tax incentive.

Moreover, since the tax benefits were part of the benefit of the bargain, under different circumstances the seller might be liable for them in the event of breach.$^{30}$ Since the seller assumes the risk that in the event of breach he may be liable for the tax benefits that should have accrued to the purchaser, then on rescission those benefits should be returned to him as part of the consideration he gave under the contract.

3. Offsetting Tax Liabilities. The third reason given by the courts for ignoring tax consequences is that upon return of the purchase price, the purchaser will be taxed for the deductions already taken. This is an apparent reference to the tax benefit rule,,$^{31}$ which provides that a deduction taken in one year for an amount subsequently recovered in a later year must be included in gross income in the year of recovery. A typical tax benefit situation involves a taxpayer who takes a charitable deduction for a contribution that is returned to him in a subsequent year. ${ }^{32}$

The rescission case differs from the cases in which the tax bene-

29 See text and notes at notes 31-32 infra.

${ }^{30}$ See text and notes at notes $49-51$ infra. Suppose the purchaser buys a limited partnership share in a real estate syndication from a promoter who also acts as developer and general partner. If seller commits a fraudulent act that deprives the limited partner of his allotted share of deductions for accelerated depreciation, the purchaser might successfully sue the general partner for damages including the expected deductions that ought to have flowed through to the purchaser. Or suppose that in the same situation the purchaser, who has received no cash flow but only $\$ 8,000$ accelerated depreciation, sues the promoter-developer for breach of fiduciary relationship, alleging that but for the developer's fraud the purchaser would have received some cash flow. Here, the purchaser should receive the damage award and be allowed to retain the tax benefits, since both were part of the benefit of the bargain. By the same reasoning, in a suit for rescission the purchaser should not be allowed to keep part of the benefit of the bargain but should restore it to the seller.

${ }^{31}$ According to Mertens, the general tax benefit rule, "not expressly stated in the Code but developed through the case law, is that if an amount deducted from gross income in one taxable year is recovered in a later year, the recovery is income in the later year." $1 \mathrm{~J}$. Mertens, Law of Federal. Income Taxation $\$ 7.34$, at 111; see Int. Rev. Code of 1954 § 111; Treas. Reg. $\S 1.111-1(a)$ (1966); Treas. Reg. 118, § 38.22(b)(12)-1; cf. Dobson v. Commissioner, 320 U.S. 489 (1943); Commissioner v. Anders, 414 F.2d 1283 (10th Cir.), cert. denied, 396 U.S. 958 (1969).

${ }^{32}$ See text and note at note 123 infra. 
fit rule has been applied, however, because the grounds for the original deduction have not been destroyed. A drilling operation cannot be undone; all that has happened is that the burden of risk has been shifted from the purchaser back to the original seller. Given that someone is entitled to the deduction for expended drilling costs, ${ }^{33}$ denying an offset to the seller because the purchaser's tax benefit will be recaptured begs the question of whether the seller should receive those tax benefits. The problem is actually circular: if the seller is awarded an offset in the amount of the purchaser's tax benefits, the purchaser is left with no tax benefit to be recaptured; if the court assumes that the purchaser's tax benefit will be recaptured, there is no gain to be awarded to the seller.

Assuming that the purchaser's tax benefit will be entirely recaptured through application of the tax benefit rule, the Cooper court's result is sound, though its reasoning is incomplete. Under the principles of rescission, as a private law matter, the seller seems entitled to recover the purchaser's tax benefits as profits. But recognition that the public law claim of the Internal Revenue Service to recapture those tax benefits overrides any private law claim of the seller properly precludes this result. A more serious defect in the Cooper court's reasoning, however, is the failure to inquire whether the purchaser's tax benefit will be entirely recaptured by the IRS. If the tax benefit rule applies, the purchaser will have the use of money saved by virtue of the deductions until the time of recapture. More important, if the tax benefit rule does not apply and the purchaser is taxed at capital gains rates on the return of deductions used to offset ordinary income, he will show a post-rescission posttax profit.

4. Amount of Offset Dependent on Tax Bracket of Purchaser. A tax oriented remedy negates all impact of this rationale; the benefit to the seller, if he takes the deduction previously claimed by the purchaser, will be determined by his own tax bracket and will not be in any way dependent on the tax bracket of the purchaser. But if a contractual offset solution is chosen, the amount of the offset will indeed vary with the tax bracket of the purchaser. This latter effect is irrelevant to the position of the purchaser in terms of the theory of rescission. As will be discussed in the next section, the condition precedent to return of the purchase price is tender of the security and all profits. That this figure is higher for the high bracket taxpayer only reflects that the bargain was more profitable

${ }^{33}$ See note 61 infra. 
for him than for a lower bracket investor. The net effect in either case is to return the investor to the position he would have been in if the sale had not been consummated.

It must therefore be concluded that the reasoning in Cooper and Wiesenberger cannot sustain denial of the seller's claim for some compensation for the tax benefits flowing from the investment.

\section{B. The Principles of Rescission Applied to Tax Benefits}

The aim of rescission is to place the parties in the position they would have been in if the sale had not been consummated. ${ }^{34}$ The rescission remedy of restitution requires the return to each party of the consideration received by the other ${ }^{35}$ Consequently, whether acting under the federal securities laws ${ }^{36}$ or common law, ${ }^{37}$ the rescinding party must return profits received from the rescinded transaction. Where the right to tax savings was part of what was bought and sold, it is, like the right to any other form of profits, part of the consideration for the sale. ${ }^{38}$ As a result, the right to receive those tax

34 See, e.g., 17A C.J.S. Contracts $\$ 438$ (1963). See generally Dobbs, Pressing Problems for the Plaintiff's Lawyer in Rescission: Election of Remedies and Restoration of Consideration, 26 ARK. L. REv. 322 (1972).

355 A. Corbin, Contracts $\S 1107$ (1964); Restatement of Restitution $\S 65$ (1937); Restatement of Contracts $\$ 349$ (1932); 17 AM. Jur. 2d Contracts $\$ 512$ (1964); 17A C.J.S. Contracts $\S 439$ (1963) and cases cited at note 11 therein. "The general rule, in some jurisdictions affirmed by statute, is that a party seeking to rescind must restore, or offer to restore, the consideration or whatever he has received under the contract. This rule does not depend on the reason for rescission." Id. $\S 439$ (footnotes omitted).

${ }^{36}$ See note 6 supra.

${ }^{37}$ The requirement that a purchaser tender back everything he has gained under a contract has ample precedent in common law rescission. For example, where the rescinded purchase is of realty, the purchaser's recovery is reduced to the extent of the value of his use and occupation. See, e.g., Doom v. Doom, 8 Ill. App. 3d 186, 289 N.E.2d 243 (4th Dist. 1972) (where the right to rescind conveyance of land exists, the grantor is entitled to an accounting for rents and profits); Mortensen v. Berzell Investment Co., 102 Ariz. 348, 429 P.2d 945 (1967) (purchaser of property, to secure right of rescission, should have offered to pay for use of land); Johnston v. Gilbert, 234 Ore. 350, 382 P.2d 87 (1963).

Similarly, on rescission of a contract for a distributorship agreement on grounds of fraud and nonperformance by defendant corporation, defendant was entitled to the cash value of inventory sold by the plaintiff. Seidling v. Unichem, Inc., 52 Wis. 2d 552, 191 N.W.2d 205 (1971). See also Bray v. Lowery, 163 Cal. 256, 124 P. 1004 (1912) (seller allowed credit for profit gained by plaintiff under contract for purchase of automobiles).

Finally, in the case of securities, although only a few state statutes expressly require a rescinding purchaser to tender dividends, interest, or other distributions received on the securities, see, e.g., Miss. CODE ANN. § 75-71-31 (1972), courts apparently impose that restriction anyway. 3 Loss 1673 (2d ed. 1961) and 6 Loss 3817 (Supp. 1969); Cross v. Pasley, 270 F..2d 88, 93 (8th Cir. 1959), cert. denied, 362 U.S. 902 (1960) (where plaintiff purchaser's recovery was reduced by the amount of receipts taken in while he held the security, though the Blue Sky Law made no reference to such a credit).

${ }^{38}$ Where tax savings do not go to the heart of the bargain between the parties, it is not 
benefits must also be returned to the seller.

The importance of tax benefits to the bargain between the parties is illustrated by recent decisions that have said that tax benefits are profits for purposes of determining whether an investment is a "security" under the federal securities laws. ${ }^{39}$ Under the test laid down in SEC v. Howey, Co. ${ }^{40}$ an "investment contract" is a security for purposes of the securities laws only if a person "invests his money in a common enterprise and is led to expect profits solely from the efforts of a promoter or a third party." 41 In Forman $v$. Community Services, Inc. ${ }^{42}$ residents of a low-middle income housing cooperative sued the individuals and corporation that had built, promoted, and sold plaintiffs' shares in the cooperative. One of the questions presented was whether the shares of a state-financed nonprofit housing corporation were securities within the meaning of the federal securities laws. While conceding that there was no possible profit on the resale of shares or on dividends, the Second Circuit said:

Profit, however, need, not be realized only in capital appreciation; equally important is the possibility of income from the investment. [One] way of realizing income . . . is the ability to partake of certain tax benefits-notably a deduction for a pro rata share of the mortgage interest payments. Investment schemes whose purpose is to provide tax losses and thereby generate deductions are usually reserved for the well-heeled, but here the opportunity to make tax savings, even for those

less obvious that they represent a form of profit but merely less obvious that such profit was received as bargained-for consideration and must therefore be tendered back. It need not follow from the argument of this comment that tax benefits must be considered in mitigating damages. Although the objective in a rescission action is to return the parties to the status quo ante, the broad aim of a damage remedy is to compensate one party injured by the act or omission of another. C. McCoRmick, HaNDBOOK ON THE LAw of DaMages $\S 137$ (1935). In a damage action, the court must determine the losses caused by the negligence or breach of the wrongful party, and it may plausibly be argued that the wrongful act or omission caused the injured party's total loss and the plaintiff's partial recoupment of the loss through tax deductions represents a collateral benefit unconnected with the defendant's acts. See, e.g., Cereal Byproducts Co. v. Hall, 16 Ill. App. 2d 79, 81-82, 147 N.E.2d 383, 384 (1st Dist.), aff'd, 15 Ill. 2d 313, 155 N.E.2d 14 (1958). In rescission, the issue is not whether the tax benefits are causally related to the defendant's acts, but rather whether the benefits were part of the consideration received under the contract that must be returned to restore both parties to the status quo ante.

39 See text and notes at notes $42-44$ infra.

10328 U.S. 293 (1946).

"Id. at 298-99.

${ }^{\star 2} 500$ F.2d 1246 (2d Cir. 1974), rev'd sub. nom., United Housing Foundation, Inc. v. Forman, 95 S. Ct. 2051 (1975). 
in a low bracket, is a substantial inducement to buy shares, where the alternative is the payment of rent with no tax benefits. ${ }^{43}$

A similar result had been reached by the Second Circuit in 1050 Tenants Corp. $v$. Jakobson; ${ }^{44}$ indeed, it has been said that the latter decision goes a long way toward setting aside the decision in Cooper $v$. Hallgarten \& Co. because it rules that tax benefits are profits. ${ }^{45}$

In reversing the Second Circuit's decision in Forman v. Community Services, Inc. ${ }^{46}$ Justice Powell's majority opinion alluded only briefly to the appellate court's discussion of tax benefits: "We know of no basis in law for the view that the payment of interest, with its consequent deductibility for tax purposes, constitutes income or profits. These tax benefits are nothing more than that which is available to any homeowner who pays interest on his mortgage." 47 But Justice Brennan, joined by Justices Douglas and White in dissent, pointed out that "the Court must surprise knowledgeable economists with its proposition . . . that profits cannot assume forms other than appreciation of capital or participation in earnings. . . . The investor finds no reason to distinguish, for example, between tax savings and after-tax income."48 As the dissent observes, the tax benefits may be available to any homeowner, but they are nonetheless profits.

In accord with the view that tax consequences must be taken into account in the remedy are cases like the rescission hypothetical where the tax consequences were at the heart of the bargain between the parties. For example, in Beggs $v$. Dougherty Overseas, Inc., ${ }^{49}$ an action for wrongful termination of a foreign employment contract, an important element of which was tax benefits, the Second Circuit allowed the plaintiff to recover the tax benefits ${ }^{50}$ that would have

4300 F.2d at 1254 .

14 365 F. Supp. 1171 (S.D.N.Y. 1973), aff'd, 503 F.2d 1375 (2d Cir. 1974). In that case, defendant promoters, who had sold shares in a cooperative housing development to the tenant plaintiffs, argued that cooperative housing shares were not securities under federal law because the purpose of the shareholder's purchase was homeownership, not profit, and that therefore the investors lacked the requisite "expectation of profit."

The court ruled that the purchasers' expectation of tax benefits satisfied the profit element of the Howey test: "When defendants convinced these residents to incorporate, one of the reasons given was availability of tax deductions of their monthly maintenance charges. Such direct monetary benefit, by any other name, is still profit." 365 F. Supp. at 1176.

${ }^{45}$ Letter from P. Snyderman, in $41 \mathrm{~J}$. TAX. 125, 126 (1974).

${ }^{16}$ United Housing Foundation, Inc. v. Forman, 95 S. Ct. 2051 (1975).

4795 S. Ct. at 2062.

$1895 \mathrm{~S}$. Ct. at 2066.

19 287 F.2d 80 (2d Cir. 1961).

${ }^{50}$ It is unclear from the reported opinion whether the tax benefits were the foreign income 
been received if the contract had not been breached. The court recognized that taxes were a major factor in the minds of the parties when they contracted because "damages were foreseeable and in the reasonable contemplation of the parties, as a result of the breach ... the income tax items were properly allowed as elements of damage." ${ }_{51}$ As in Beggs, the tax benefits in the rescission case are at the heart of the bargain. Thus, since the tax benefits are bound up with the contractual relationship of the parties, they should be considered in awarding damages.

The Beggs case illustrates an important distinction between the cases relied upon in Cooper, which all involved some type of tort, and the rescission case. Like the rescission case, Beggs was an action based on a contract between two parties. As the court noted in Beggs, tax consequences in measuring a damage award in which tax matters went to the heart of the bargain is consistent with the general rule limiting damages to those within the contemplation of the parties.

It thus appears that the tax benefits generated by the investment should be returned to the seller. The next issue to be considered is whether this result should be accomplished by an offset to the seller's liability for returning the purchase price to the purchaser or by appropriate tax treatment.

\section{The Interplay Between Private and Public Law}

As a strictly private law problem, the theory underlying rescission requires a transfer of all profits, including tax benefits, to the original seller. But profits earned in the form of tax benefits cannot be treated solely as a private law issue. Since the problem actually involves three parties-the seller, the purchaser, and the Government-a court ordering rescission should always investigate the manner in which Government will approach the rescinded transaction before awarding the seller an offset to his contractual liability. This part of the comment analyzes the two alternative approaches that the Government can take with respect to the rescinded transaction and suggests how these approaches should be considered in determining rescission awards. The comment concludes that the most efficient and equitable method of solving the interplay prob-

taxes for which the employer had contracted or the United States taxes the plaintiff was forced to pay in the absence of foreign tax liability. The latter seems more plausible.

st 287 F.2d at 83. 
lem is to return the tax benefits to the seller by means of a tax deduction rather than an offset to the vendor's contractual liability.

\section{A. Alternative Methods of Treating Rescission}

There are two alternative ways to conceptualize rescission. On the one hand, rescission can be viewed as a nullification of the original transaction, rendering the initial sale void ab initio. Since this approach in effect creates a legal fiction that the sale never took place, the tax consequences of the initial contract are nullified, and the seller is left with a claim to a nonexistent tax benefit. According to the second approach, the rescission is a separate transaction, conceptualized as the seller's repurchase of the security for the original purchase price. Under this latter view, the tax consequences of the contract and its subsequent rescission are recognized independently. ${ }^{52}$

If the purchaser earned no profits on the security during the time he had held it, the only difference between the two alternative approaches concerns the subsequent taxation of the parties. If the sale was void ab initio, the vendor, who took a capital gain on the original sale, takes back the security at his original cost basis, eliminating whatever capital gain he may have recognized at the time of the initial transaction. Of course, if rescission takes place in a tax year subsequent to the year of the original sale, the seller's capital gains adjustment is accomplished by means of an amended return. The purchaser is obviously not taxed at all when he has earned no profits on a security the sale of which was void ab initio. On the other hand, if the rescission is treated as a separate transaction, ${ }^{53}$

\footnotetext{
32 As an independent transaction, the rescission seems to be a "sale or exchange" within the provisions of section 741 of the Code. INT. REv. CoDE of 1954, $\$ 741$. That section provides that the gain or loss resulting from the sale or exchange of a partnership interest shall be considered as gain or loss from the sale or exchange of a capital asset, except for unrealized receivables and inventory items that have appreciated substantially in value. See id. $\$ 751$ (a). (b). On section 751 items, the measure of the gain or loss is the difference between the amount realized and the adjusted basis of the partnership interest for such items. But for the bulk of the partnership items, the measure of gain or loss from the sale or exchange of a partnership share is determined by the general basis rules for property under section 1011(a) of the Code. Id. $\S 1011$ (a). As a result, the basis of a purchased interest will be its cost. Under the facts of the rescission hypothetical considered in this comment, in the event the rescinding purchaser is given capital gains treatment his basis will be cost basis $(\$ 10,000)$ minus deductions $(\$ 8,000)$. For the rules determining calculation of the adjusted basis of a partner's interest see id. $\S 705$.

${ }_{53}$ In Mortimer L. Schultz, 59 T.C. 559 (1973), the court held that a cash basis taxpayer had to report capital gains arising from a stock sale in the year of sale even though in a subsequent tax year the sale was challenged and the taxpayer had to repay part of the proceeds. The court held that partial repayment was a new transaction rather than a partial
} 
the seller's original capital gain stands, and he takes the security back at a higher basis-namely, the amount of the purchase price. Once again, there is no tax levied on the purchaser who earned no profit on the security.

But if the purchaser has earned profits on the security, even in the form of tax benefits, the situation is more complicated and the alternative approaches to rescission assume greater importance. In the first place, adjustments must be made to the repurchase price to account for profits that have accrued to the latter original purchaser. And if those profits are in the form of tax benefits, the Government will be interested in the consequences that the alternative approaches will have on tax revenue. ${ }^{54}$

Those courts that have confronted the issue of the nature of rescission have not uniformly adopted either approach. ${ }^{55}$ Neverthe-

nullification of the original transaction and thus had no effect on the taxpayer's tax liability for the original transaction. Id. at 563.

In Hope v. Commissioner, 471 F.2d 738 (3d Cir.), cert. denied, 414 U.S. 824 (1973), the court held that a cash basis taxpayer who sold stock in 1960 was liable for tax on the sale even though he sued for rescission later that year. The court denied that part of the transaction was actually rescinded in that year, but said that if actual rescission had taken place in 1960 "it might well have been recognized for tax purposes." Id. at 743.

54 Cf. Van Den Wymelenberg v. United States, 397 F.2d 443, 445 (7th Cir.), cert. denied, 393 U.S. 953 (1968): "As to the parties to the reformed instrument the reformation relates back to the date of the original instrument, but it does not affect the rights acquired by nonparties, including the Government."

${ }^{35}$ The Fourth Circuit has held that the tax consequences of a completed transaction are not altered by its subsequent rescission in a later year. Penn v. Robertson, 115 F.2d 167, 175 (4th Cir. 1940); Brown v. Commissioner, 9 CCH TAX Cr. MEM. 1054, 1060 (1950) (later partial rescission of sale does not affect reporting of income in year of sale). In Penn, the court also held, however, that a "genuine rescission" extinguishes the rescinded transaction's tax consequences that occur in the year of rescission. 115 F.2d at 175. It has been held, moreover, that the tax consequences of a completed transaction may be altered by neither a nunc pro tunc reformation agreement, Davis v. Commissioner, 55 T.C. 416, 426-29 (1970), nor judicial reformation. Van Den Wymelenberg v. United States, 397 F.2d 443, 445 (7th Cir.), cert. denied, 353 U.S. 553 (1968). But cf. Flitcroft v. Commissioner, 328 F.2d 449 (9th Cir. 1964).

On the other hand, it has been argued in the context of rescission of a corporate merger that dicta in two decisions indicate that rescission may be a nontaxable event. Littenberg \& Reinstein, Deconglomeration-Tax and Business Problems Associated with the Divestiture of a Recently Acquired Business, 24 U. So. CaL. 1972 TAx INST. 101, 118-20, discussing Hope v. Commissioner, 55 T.C. 1020 (1971), aff'd, 471 F.2d 738 (3d Cir.), cert. denied, 414 U.S. 824 (1973); Ripley Realty Co. v. Commissioner, 23 B.T.A. 1247, 1249 (1931), aff'd per curiam, 61 F.2d 1038 (2d Cir. 1932); see B. Bittker \& J. Eustice, Federal Income Taxation of Corporations and Shareholders 14-148 (3d ed. 1971): "[T]f the entire transaction is rescinded and the original consideration returned 'in kind', it could at least be argued that no gain or loss should be recognized to either party in this situation on the ground that matters merely revert to their preacquisition status. ..."

In the rescission hypothetical, it can hardly be said that matters revert to their pretransaction status. By virtue of the tax benefits, the purchaser's position relative to the status quo ante has changed. In this case, at least, the argument for treating the rescission as a 
less, the Internal Revenue Service has taken, and apparently will continue to take, the position that rescission is to be treated as a separate taxable transaction..$^{56}$

1. Rescission Awards Under the Nullification Approach. If the Internal Revenue Service pursues the nullification approach, upon rescission it will attempt to recoup the purchaser's tax benefits either by requiring the purchaser to file an amended return or by application of the tax benefit rule. Since the original transaction is viewed as void ab initio, the amended return solution is applicable. But if the rescission takes place in a subsequent tax year, use of the tax benefit rule is more efficient because it would not require amendments to all tax returns of the purchaser for the intervening years.

The policy underlying the tax benefit rule is that "property having once served to offset taxable income (i.e., as a tax deduction) should be treated, upon its recoupment, as the recovery of that

taxable event appears strong.

In cases analogous to rescission, where real property is reacquired by the seller either upon the purchaser's default or by repurchasing the land, the fact of reacquisition does not alter the taxability of the original transaction. In short, the later reacquisition is not a nullification of the earlier event but an independently recognizable event. See 3 P-H 1975 FED. TAXES If 20,230. The reasons for this policy are compelling in the rescission case as well. Cf. A.W. Shaw, 13 B.T.A. 716 (1928).

In two cases closer to the rescission hypothetical, courts have applied this notion that a subsequent reacquisition will not nullify tax consequences of an earlier transaction. In Ripley Realty Co., 23 B.T.A. 1247 (1931), aff'd, 61 F.2d 1038 (2d Cir. 1932), the Board of Tax Appeals held that a seller who had settled an action for fraud by taking back the real estate lots he had sold nevertheless had to recognize the tax consequences of the earlier sale since the original transaction was voidable rather than void ab initio. The Board speculated that if the ground for rescission had been that the sale was void ab initio a different tax result might have obtained. Id. at 1249.

Similarly, in a case that deals directly with the disposition of a partnership interest, Reeves v. United States, 173 F. Supp. 779 (M.D. Ala. 1959), the court held that the sale of a partnership interest was taxable even though that share was repurchased by the original seller in the same year. The court said that the gain from the first transaction was taxable as a capital gain to the seller, despite the taxpayer's claim that the sale was rescinded and therefore that no taxable capital gain could have been realized. Id. at 781, accord, Branum v. Campbell, 211 F.2d 147 (5th Cir. 1954) (repurchase of partnership interest increased taxpayer's basis but did not alter capital gain on original sale); cf. Bancitaly Corp., 34 B.T.A. 494, 514-16 (1936).

These cases support the contention that rescission will be treated as an independently recognizable transaction rather than a nullification of the seller's original capital gain. As an independent transaction, the rescission and restitution through the seller's repurchase might be accorded capital gains treatment. Since the seller was given capital gain on the original sale, the purchaser may argue that he should be given capital gain on the subsequent resale.

${ }^{58}$ Littenberg \& Reinstein, supra note 55, at 121; Zeigler, Extricating a Corporation From a Change in Circumstances: Reversing or Modifying a Reorganization or a Liquidation, N.Y.U. 29TH InST. ON FED. TAX. 313, 330-31 (1971). 
which had previously been deducted." 57 To achieve that policy, the rule requires that amounts deducted from gross income in a given taxable year that provide a tax benefit in that year must, if recovered in a later year, be included in the taxpayer's gross income in the later year..$^{58}$

The tax benefit rule would require a return to gross income of the $\$ 8,000$ tax loss in the hypothetical considered in this comment. ${ }^{59}$ If the $\$ 8,000$ tax loss is composed of drilling and development expenditures in addition to the initial purchase price, the purchaser will have incurred an $\$ 8,000$ actual loss by the time of rescission, and the vendor would have to reimburse the purchaser for the loss in addition to returning the original purchase price. Assuming that the tax loss had offset income from other sources, the taxpayer would be required to return the amount of the previous loss deduction to gross income upon the recoupment of the loss in the year of rescission..$^{60}$ Alternatively, if the purchaser's share of the $\$ 8,000$ partnership expenditure was taken from the purchaser's $\$ 10,000$ capital interest, the vendor's return of the $\$ 10,000$ purchase price on rescission enables the purchaser to recoup the previous $\$ 8,000$ tax loss, ${ }^{61}$ and as a result the purchaser would be required to return

${ }^{57}$ Alice Phelan Sullivan Corp. v. United States, 381 F.2d 399 (Ct. Cl. 1967). See generally Plumb, The Tax Benefit Rule Today, 57 Harv. L. Rev. 129 (1943).

35 According to Mertens, the general tax benefit rule, "not expressly stated in the Code but developed through the case law, is that if an amount deducted from gross income in one taxable year is recovered in a later year, the recovery is income in the later year." $1 \mathrm{~J}$. Mertens, Law of Federal Income Taxation $\$ 7.34$ (rev. ed. 1974) (footnotes omitted). Statutory recognition of the rule is found in section 111 of the Code, which provides for the exclusion from gross income of income attributable to the recovery of bad debts, prior taxes, and delinquency amounts that were deducted in an earlier year but provided no tax benefit when deducted. INT. Rev. CoDE of 1954, $\$ 111$. Section 111 does not limit the general rule which was extended to the recovery of "all other 'losses, expenditures, and accruals" "made the basis of deductions from gross income for prior taxable years. 1 J. MERTENs, supra, \& 7.34, discussing Dobson v. Commissioner, 320 U.S. 489 (1943) (dealing with comparable provisions of 1939 Code).

51 The Cooper court seems to have had this alternative in mind when it wrote that if the rescinding plaintiff recovered his purchase price in full, that sum would be subject to appropriate tax treatment in his return as against the deductions and allowances taken in earlier years. Cooper v. Hallgarten \& Co., 34 F.R.D. 482, 486 (S.D.N.Y. 1964).

" See, e.g., Lloyd H. Faidley, 8 T.C. 1170 (1947) (recoupment of loss on investment in an oil venture); $1 \mathrm{~J}$. Mertens, LaW of Federal Income TaXation $\$ 7.37$ (rev. ed. 1974).

"If a portion of the $\$ 8,000$ deduction did not represent an actual expenditure by the purchaser or the partnership, as for example cost depletion, INT. REv. CODE OF 1954, $\$ 612$, that portion would not be reimbursed by the vendor because it was not part of the actual loss. The divestiture of the partnership interest and the recovery of the actual losses incurred thereon would seem, however, to compel a return to gross income of all deductions, including those for which no expenditure was made. Cf. Douglas v. Commissioner, 322 U.S. 275 (1944), upholding a Treasury Regulation that required depletion deductions taken in prior 
$\$ 8,000$ to gross income in this latter case as well.

Application of either an amended return requirement or the tax benefit rule to the hypothetical situation set forth in the introduction to this comment would require the purchaser to restore $\$ 8,000$-the amount of the claimed tax loss-to gross income. Since restoration of that amount to gross income eliminates the purchaser's tax benefit, a court would have no justification for awarding the vendor an offset to the initial purchase price. In fact, if a court awards a $\$ 4,000$ offset to the vendor-the value of an $\$ 8,000$ tax loss to a purchaser in a 50 percent tax bracket-it would in effect preempt the claim of the Internal Revenue Service to tax benefits that actually belong to the Government under the nullification approach.

2. Rescission Awards Under the Independent Transaction Approach. Both the vendor and the purchaser will argue that the rescission should be treated as an independent taxable transaction rather than as a nullification of the original sale. ${ }^{62}$ The purchaser will insist on the independent transaction approach since his gain on resale may be taxed at the lower capital gains rates, ${ }^{63}$ rather than ordinary income rates, leaving him with a net tax benefit. ${ }^{64}$ And although the seller foregoes an opportunity to recoup the capital gains tax he may have paid on the initial transaction, he will nevertheless argue for the independent transaction approach since he can assert a claim to the purchaser's recognized tax benefits.

years by a lessor on receipt of advance royalties from a lessee to be restored to the lessor's gross income if the lease was terminated before any minerals had been extracted.

${ }^{62}$ Another view that might be urged by the purchaser as to the subsequent taxation of the rescission is that neither gain nor loss need be recognized. This argument, though it is unlikely to be successful, would preclude recognition of gain or loss by analogizing the rescission to the reacquisition of real property to satisfy indebtedness to the original vendor. Where the sale of real property gives rise to an indebtedness to the seller for which the property itself stands as security, section 1038(a) of the Code generally provides that the seller recognizes neither gain nor loss. INT. REv. CoDE of 1954 § 1038(b). But see id. § 1038(d). The basis of such property is the adjusted basis of the indebtedness secured by the property. Id. $\S 1038$ (c). Analogizing the seller's release of indebtedness under section 1038 to the seller's return of the purchase price in the rescission case is unlikely to be successful because section 1038 applies to taxation of the seller, not the purchaser.

${ }^{63}$ A partnership interest is considered a capital asset when sold or exchanged. INT. REv. CODE of 1954, $\S 741$. Ordinary income is realized, however, when that interest includes unrealized receivables or substantially appreciated inventory. Id. \& 751. Unrealized receivables generally are existing rights to payment for past or future services or delivery of goods. $I d$. $\$ 751$ (c). An inventory item is substantially appreciated if, at the transfer or distribution date, the fair market value of all inventory exceeds both 120 percent of its aggregate adjusted basis and 10 percent of the value of all the firm's property except money. Id. $\$ 751$ (d).

${ }^{64}$ For a suggestion that the purchaser might be taxed on the rescission at capital gains rates, see letter from N.A. Zilber, in 42 J. TAx. 127 (1975). 
The Internal Revenue Service has consistently characterized rescission as an independent taxable transaction, not only so that the seller's initial capital gain will stand but also for reasons of administrative efficiency and the integrity of the annual accounting system. ${ }^{65}$ Moreover, under this approach, the IRS apparently has the option of recapturing the purchaser's tax benefits either as ordinary income under the tax benefit rule ${ }^{66}$ or, perhaps more appropriately, by means of capital gains treatment. ${ }^{67}$ If the court ordering rescission anticipates application of the tax benefit rule, the purchaser will show no post-rescission gain; consequently, the court should accord priority to the Government's claim to recoup the tax benefits and deny the seller's claim for an offset. But if the purchaser is allowed some capital gains treatment on his recovery of his tax loss, then he will show a post-rescission gain in the amount of the difference between the amount of the deductions times the rate at which the ordinary income offset by the deductions would otherwise have been taxed and the portion of the recovery taxed at capital gains rates times the capital gains rate of taxation. ${ }^{68}$ In short, the difference is that between the rate of ordinary tax and the rate of capital gains tax; the original purchaser will show approximately a 50 percent post-rescission gain after taxes on that portion of the recovery treated as the sale of the purchaser's partnership interest.

To the extent the purchaser's recovery (on resale) is taxed at capital gains rates, the seller's claim for an offset should be more seriously considered. The purchaser is otherwise placed in a better position than he occupied in the status quo ante because he in effect makes a profit on the rescinded transaction. This profit, like any other made under a subsequently rescinded contract, should be transferred to the seller.

The problems in calculating an offset, whether for the full

${ }^{65}$ See Littenberg \& Reinstein, supra note 55 at 117; cf. Note, The Tax Benefit Rule, Claim of Right Restorations, and Annual Accounting: A Cure for the Inconsistencies, 21 VAND. L. REv. 995 (1968).

" Cf. Commissioner v. Anders, 414 F.2d 1283 (10th Cir.), cert. denied, 396 U.S. 958 (1969). In that case, the court held that the amount received for rental items in a sale of corporate assets preceding complete liquidation of a corporation was taxable as ordinary income to the corporation under the tax benefit rule if the cost of such items had been fully expensed at the time of purchase. Id. at 1287. See also Hempt Bros. Inc., v. United States, 490 F.2d 1172, 1179-81 (3d Cir.), cert. denied, 419 U.S. 826 (1974); Connery v. United States, 460 F.2d 1130, 1133 (3d Cir. 1972); Spitalny v. United States, 430 F.2d 195, 196 (9th Cir. 1970); Note, Tax-Free Sales in Liquidation under Section 337, 76 HaRv. L. Rev. 780, 793-94 (1963).

"See notes 52-53, 63 supra.

- See note 52 supra. 
amount of the purchaser's tax benefits or merely for that portion accorded capital gains treatment, are complex. In the first place, serious inequities will result if the court awards an offset for the full value of the purchaser's tax benefits. For example, in the hypothetical discussed above, the court would award the seller a $\$ 4,000$ offset to his liability to the purchaser-the tax benefit value of an $\$ 8,000$ loss to a taxpayer in a 50 percent bracket. The purchaser would then receive $\$ 6,000$ from the seller in exchange for a security in which his adjusted basis is $\$ 2,000$ (his $\$ 10,000$ cost basis minus the $\$ 8,000$ deducation). The purchaser would have to recognize a gain of $\$ 4,000$ over his adjusted basis. Assuming that the entire gain would be given capital gains treatment at a 25 percent rate, he would have to pay $\$ 1,000$ in taxes, thus losing $\$ 1,000$ on the rescission. Clearly this result is unacceptable.

But if no offset is awarded, and if the purchaser is allowed capital gains treatment of the "sale" or "repurchase by the vendor", an equally unacceptable result obtains. The original purchaser would pay a $\$ 2,000$ capital gains tax on his $\$ 8,000$ gain $(\$ 10,000$ repurchase price minus $\$ 2,000$ basis), leaving him with a $\$ 2,000$ profit on the rescission. One possible solution would be to award an offset to the seller and at the same time step up the purchaser's adjusted basis in the security. ${ }^{69}$ This step-up in basis finds no support in the current Code, and it is not analogous to other Code provisions for adjustments in basis. Another solution would be to reduce the offset by an amount calculated to return the purchaser to the status quo ante.

The problem of calculating the offset might be expressed as follows: (Purchase Price - Offset - Adjusted Basis) $\times$ Rate of Taxation $=$ Tax Benefit - Offset. Or, substituting the figures from the hypothetical, with " $\mathrm{X}$ " representing the offset: $(\$ 10,000-\mathrm{X}-$ $\$ 2,000) \times .25=\$ 4,000-\mathrm{X}$. The appropriate offset thus equals $\$ 2,667$ :

${ }^{69}$ To take a simple example, the $\$ 4,000$ tax benefit to the purchaser in our hypothetical could be restored to the vendor as an offset to the purchase price, and the vendor would then return only $\$ 6,000$ to the purchaser. Since the purchaser's basis in the security is $\$ 2,000$, he would ordinarily be taxed on a $\$ 4,000$ gain. If the purchaser's basis in the security is adjusted upward by $\$ 4,000$, however, he would recognize no gain on the transaction and would be restored to the status quo ante. The adjustment to basis is not necessarily equal to the offset. If the purchaser had been in a 25 percent tax bracket, the tax benefit on an $\$ 8,000$ deduction would be only $\$ 2,000$. If the tax benefit were offset against the seller's liability, the purchaser would receive $\$ 8,000$, or $\$ 6,000$ over his adjusted basis. The purchaser's adjusted basis would have to be increased by $\$ 4,000$ in order to preclude recognition of gain. This is an unnecessarily complicated procedure that is, in any event, unsupported by any present Code provision. 
If the purchaser receives back the purchase price minus the offset, or $\$ 7,333$, he will show a gain of $\$ 5,333$ over his adjusted basis of $\$ 2,000$. At a capital gains rate of 25 percent, the purchaser would then pay about $\$ 1,333$ in taxes. Since the value of his tax benefit was $\$ 4,000$, and he has restored $\$ 2,667$ to the vendor in the form of an offset, he is left with about $\$ 1,333$ in post-rescission gain before taxes. After the purchaser pays the appropriate taxes on his capital gain, he is in effect restored to the status quo ante.

These figures are predicated on the assumption that the purchaser is taxed at capital gains rates. But if the tax benefit rule applies, and the purchaser is taxed at ordinary (50 percent) income rates, the formula yields an offset equal to zero. This accords with the crucial difference between the two cases: in the first case, because the purchaser is taxed at capital gains rates, he is left with a post-rescission post-tax gain on the contract, which should be transferred to the original seller as an offset; in the second case, where the tax benefit rule applies, the purchaser is restored to the status quo ante without the award of an offset. Application of this formula thus prevents the purchaser from making a profit on the rescission and ensures an accurate and convenient method of calculating the offset to the vendor.

When discussing the use of the tax benefit rule under the nullification approach, it was noted that an offset would transfer money from the Government to the seller by preempting the Internal Revenue Service's claim to a recapture of the tax benefits. That objection does not apply to an offset when the rescission itself is taxed. In the latter case, the offset merely transfers a post-rescission post-tax gain from the purchaser to the vendor.

There are, nevertheless, two policy objections that might be raised against the use of an offset even when the rescission is taxed as an independent transaction. First, it can be argued that the amount of the offset should not be dependent on the income tax bracket of the purchaser. ${ }^{70}$ For example, the purchaser in our hypothetical had to accept an offset of $\$ 2,667$ based on his ordinary and capital gains tax rates of 50 percent and 25 percent respectively. If that purchaser instead faced ordinary and capital gains tax rates of 25 percent and $121 / 2$ percent respectively, he would have been subjected to an offset of about $\$ 1,143$. Thus, a taxpayer in the 25 percent bracket would receive back about $\$ 8,857$ from the vendor on

70 See Cooper v. Hallgarten \& Co., 34 F.R.D. 482, 486 (S.D.N.Y. 1964); letter from N.A. Zilber, in 42 J. TAx. 127 (1975). 
rescission, while a purchaser in the 50 percent tax bracket received back only $\$ 7,333$. Since both purchasers paid the same amount for the security-that is, there was no price discrimination according to their tax brackets-it might be said they should receive back an equal amount on rescission.

This is only an apparent anomaly, however, because both purchasers are restored to the status quo ante; they are both left with neither post-rescission post-tax gain nor loss. The amount of tax benefits that each of the two investors stood to gain from the investment varied directly with their tax brackets. To require the two purchasers to tender back the same offset on rescission would leave the purchaser in the lower bracket relatively worse off than the high bracket taxpayer with respect to their positions in the status quo ante.

Second, it might be objected that measuring the offset to the vendor by the purchaser's actual tax benefit necessarily involves discovery of the purchaser's tax returns, thus violating the confidentiality of purchasers' tax returns and creating a chilling effect on actions for rescission. Moreover, it can be argued that this discovery will produce greater administrative costs for the courts. Unlike cases in which the purchaser's profit was represented by cash flow, the profit due to tax benefits cannot be established by discovery of the relevant partnership records. And unlike cases in which the tax benefit rule applies, discovery of the purchaser's tax returns is initiated in the interest of a private party.

Although a few courts ${ }^{71}$ have held that federal statutes providing for confidentiality of income tax returns ${ }^{72}$ create an absolute privilege, the accepted view is that such tax returns are not wholly privileged documents, but are subject to discovery. ${ }^{73}$ The policy of liberal pretrial discovery must be balanced against the policy assuring the taxpayer of privacy in order to encourage full disclosure on his returns. When the relevant information may be discovered in other ways, courts will refuse to order production of tax returns. ${ }^{74}$ But where the income of a party is at issue, and other documents

$"$ See, e.g., Austin v. Aluminum Co. of America, 15 F.R.D. 490 (E.D. Tenn. 1954); O'Connell v. Olsen \& Ugelstadt, 10 F.R.D. 142 (N.D. Ohio 1949).

${ }^{2}$ INT. Rev. CODE of 1954, $\S \S 6103,7213(a)$.

${ }^{73}$ See, e.g., Taylor v. Atchison, T. \& S.F.R.R., 33 F.R.D. 283 (E.D. Mo. 1964). The Federal Rules of Civil Procedure were amended in 1970 to eliminate the requirement of a showing of "good cause." See FED. R. Crv. P. 34.

74 Cooper v. Hallgarten \& Co., 34 F.R.D. 482, 485 (S.D.N.Y. 1964) (noting that the defendants could reapply for the production of returns). 
will not suffice, production of tax returns may be compelled. ${ }^{75}$ Of course, the court can limit discovery to those portions of the purchaser's returns that bear on calculation of the offset. ${ }^{76}$ Alternatively, a court might itself use the returns to calculate the offset without revealing them to the vendor. ${ }^{77}$

The disadvantages and administrative costs that result from use of the offset solution may be minimized in these ways. Moreover, its disadvantages seem more than outweighed by the clear inequity that would otherwise result from taxing the purchaser at capital gains rates on the rescission-namely, leaving the purchaser better off than in the status quo ante, while the seller will have given up the use of a tax shelter investment without gaining any compensation for its use.

\section{B. The Case for Awarding the Seller a Tax Deduction in the Year of Rescission}

From the seller's point of view, application of the tax benefit rule under the nullification approach and application of the offset formula under the independent transaction approach are both less than satisfactory. Under the nullification approach the seller is not entitled to an offset to the purchase price, and the offset formula in the independent transaction approach awards him at best a portion of the purchaser's tax benefits. The seller can legitimately claim that the whole of the purchaser's tax benefit ought to be restored to him as a private law matter, regardless of whether the tax benefit rule applies or some capital gains treatment is allowed.

As a public law matter, however, the deductions were originally given for (paper) losses sustained by the purchaser. Since the purchaser subsequently recoups his losses on rescission, the IRS can assert a legitimate claim to the tax benefits that were granted. Although the seller may object that the offset solution outlined above is a mere compromise, it may be noted that the compromise is not inconsistent with the seller's contractual argument. Profit in the form of tax benefits earned by the purchaser resulted not simply from the actions of the purchaser and seller in transferring rights to

${ }^{75}$ See 8A J. Mertens, Law of Federal Income Taxation $\$ 47.53$; see Curtier v. Allied N.H. Gas Co., 101 N.H. 205, 137 A.2d 405 (1957); C. McCormick, Evidence $\S 112$, at note 59 (2d ed. 1972).

is See, e.g., Taylor v. Atchison, T. \& S.F.R.R., 33 F.R.D. 283 (E.D. Mo. 1964).

"Cf. DeCarvalho v. Gonsalves, 262 A.2d 630 (R.I. 1970); Mandell v. Yellow Cab Co. of Cleveland, 170 N.E.2d 296; 13 Ohio Op. 2d 199, 84 Ohio L. Abs. 524 (1958). See also State ex rel Boswell v. Curtis, 334 S.W.2d 757 (Mo. App. 1960). 
the security, but also from the allowance of tax deductions by the Government.

It is beyond the jurisdiction of a court ordering rescission to restore the purchaser's tax benefits to the seller, thereby denying or at least deferring the Government's recoupment of the deduction. ${ }^{78}$ Jurisdiction is conferred only to decide the private contractual dispute between the parties, not to adjudicate a tax claim. Moreover, the IRS would be an interested party in any such action that determined a tax claim, and it would be necessary to allow the IRS to represent the Government's interest in any private suit for rescission in which tax benefits are involved.

A more efficient solution to the seller's claim that he has been deprived of substantial tax benefits to which he is entitled under private law would be for the IRS to award the seller a tax deduction in the year of rescission. Under this solution, the private contractual dispute between the vendor and purchaser would be resolved as though no tax benefits had been involved. The IRS would recoup the purchaser's tax benefit by recapturing earlier deductions under the tax benefit rule. If the seller's claim was thought meritorious, the IRS could award the seller in the year of rescission a deduction equal to that taken by the purchaser.

This solution is unsupported by any present Code provision and raises problems similar to those presented by the tax benefit rule. The latter rule provides that a taxpayer who recoups a sum previously deducted may be taxed on that recovery at ordinary rates only to the extent the previous deductions were tax beneficial. If the grant of tax losses to the seller is to proceed along similar lines, such deductions should be returned to the vendor only to the extent their loss caused a tax detriment in the years they would have accrued to the vendor. Thus, the IRS would have to ascertain whether the purchaser gained a benefit from the deductions by having sufficient

${ }^{78}$ The doctrine of sovereign immunity bars suits against the federal government unless Congress has by statute waived immunity. Congress has specifically provided that federal district courts can entertain suits against the federal government brought by taxpayers contesting erroneously collected taxes. See 28 U.S.C. $\$ 1346$ (1970). But in pressing the claim of an offset, the vendor is really attempting to preempt future taxation; in fact, he is attempting to preempt future taxation not of himself but of the purchaser. Consequently, section 1346 does not give the district courts jurisdiction to award offsets for tax benefits. Cf. Phillips v. United States, 346 F.2d 999 (2d. Cir. 1965) (holding that sovereign immunity bars suit against federal government by an individual attempting to recover monies which the government had collected from a corporation and which the corporation allegedly owed to plaintiff); Nehf v. United States, 302 F. Supp. 356 (N.D. Ill. 1969) (holding that the doctrine of sovereign immunity bars a suit against the federal government for monies that assignees alleged should have been paid to them by a third party rather than to the federal government). 
taxable income to be offset by the deductions, and also whether the seller had sufficient income that was otherwise taxable during the years of the purchaser's deductions such that the loss of those deductions was tax detrimental. Application of this "tax detriment" rule is compelled by this kind of solution, and it makes the solution neither as simple nor as appealing as it might otherwise appear.

Nevertheless, this solution presents an important advantage over a contractual solution under which a court would deduct from the seller's liability the amount of the purchaser's tax benefit. When the seller is in a low tax bracket and the purchaser in a high bracket, it seems somewhat inequitable to award the former an offset for a savings of income taxed at the latter's marginal rate. By allowing the seller to take deductions rather than an offset to the repurchase price, the "tax benefit-tax detriment" solution awards the seller a tax benefit which is measured at his own marginal rate of taxation.

But like the tax benefit rule, awarding a deduction to the seller in the year of rescission will be imprecise where tax rates have changed. ${ }^{79}$ The tax benefit rule, having once ascertained that the deductions were tax beneficial to the purchaser in the years they were taken, proceeds to tax the purchaser on those deductions as ordinary income at current rates. ${ }^{80}$ Similarly, the hypothetical "tax detriment" rule, having once ascertained that the deductions would have been tax beneficial to the vendor in the years they were taken by the purchaser, proceeds to award the seller deductions that will offset income taxed at current rates. In either case, the taxpayer's tax bracket in the current year, rather than in the years the deductions were in fact taken, will be dispositive.

Where the purchaser is in a higher bracket in the year of recovery, the tax benefit rule will tax the recovery of those deductions at a rate higher than the income they originally offset. Similarly, where the seller is in a lower bracket in the year of recovery than in the years the deductions were taken by the purchaser, the deductions will be worth less to him than if he had taken them when they had accrued. And even where the seller is in the same bracket, because he receives in one year deductions that would have been spread over

"See generally Note, The Tax Benefit Rule, Claim of Right Restorations, and Annual Accounting: A Cure for the Inconsistencies, 21 VAND. L. REv. 995 (1968).

so See Alice Phelan Sullivan Corp. v. United States, 180 Ct. Cl. 659; 381 F.2d 399, 403 (Ct. Cl. 1967):

To insure the vitality of the single-year concept, it is essential not only that annual income be ascertained without reference to losses experienced in an earlier accounting period, but also that income be taxed without reference to earlier tax rates. . . . 
several years, deductions that would have offset income taxed at his highest marginal rates in previous years may now offset income taxed at lower marginal rates as well. Of course, from the seller's point of view, an imprecise award is better than no award at all.

Additional difficulties would be created if the IRS awarded a post-rescission deduction or tax loss to the vendor. For example, the possibility of collusion is increased. A seller and purchaser might agree that in years when the seller is in a low bracket, he will sell to the purchaser, who will rescind when the seller is in a high bracket. This collusion would enable the vendor to take deductions that offset income taxed at the highest rates. By placing a premium on the year in which the rescission takes place, the "tax benefit-tax detriment" solution enables the seller and purchaser to trade off tax benefits, each rescinding when the other is in a high bracket and selling when in a low bracket.

Despite these difficulties, there are strong policy reasons to award the seller deductions in the year of rescission equivalent to those taken by the purchaser and subsequently recaptured by the IRS. The deductions allowed to the purchaser can be viewed as a tax expenditure by the Government-a form of subsidy in the nature of an interest-free loan. ${ }^{81}$ The subsidy is designed to encourage investment in certain areas, such as the sinking of oil and gas wells. If the seller is to receive all or part of the government's rightful claim to recoup the tax expenditure, that claim should be adjudicated not as a matter of private contract law but rather as a matter of public or agency law. Since the purpose of the government's "tax expenditure" has been fulfilled, someone, in this case the vendor, should get the tax benefit.

Because the seller returns the purchase price plus interest to the purchaser, ${ }^{82}$ the situation after rescission is comparable to the repayment by the vendor of a $\$ 10,000$ loan from the purchaser. Since, retrospectively, the $\$ 10,000$ is really the seller's money, the

${ }^{81}$ S. Surrey, Pathways to Tax Reform 6-29 (1973); see Lee, Real Estate as a Tax Oriented Investment, 49 Notre DAME L. REv., 477, 493 (1974) (a purchaser of a tax shelter is "co-venturing" with the Government).

82 See Securities Act of 1933, § 12(2), 15 U.S.C. \& 771(2) (1970). Because the seller must pay interest on the purchaser's money, it might be argued on behalf of the seller that another basis for an offset would be the interest saved by the purchaser by virtue of the tax deferral gained from the contract. Unless the seller's liability for the purchase price is reduced accordingly, the purchaser will show a net post-rescission post-tax gain, even assuming full recapture. Where attempted, however, this claim has been rejected. See Johns Hopkins U. v. Hutton, 297 F. Supp. 1165 (D.Md. 1968), modified on other grounds, 422 F.2d 1124 (4th Cir. 1970), cert. denied, 416 U.S. 916 (1974). 
cost of sinking the well has been borne by the seller. If the rescission is treated as a separate transaction, and the seller's initial capital gain stands, he reassumes ownership of the security at a new $\$ 10,000$ cost basis. Unless some or all of the deductions are awarded to the seller, he is doubly penalized; not only will he have paid capital gains tax on the initial sale, but he will be uncompensated for the loss of the early tax beneficial years of the investment, during which most of the tax losses of the investment will accrue. On any subsequent resale to another purchaser, the seller would pay less capital gains tax than if the original transaction had never taken place. But the net result is that taxation, far from being deferred, has been borne in a relatively early year. This result is inconsistent with the aim of providing tax deductions that defer tax expenses in order to encourage investment. And it is inconsistent with the restitutionary remedy of rescission, for by losing the early tax loss years of the investment the seller is relatively worse off than in the status quo ante. Because these early tax loss years have been "used up", the seller is not likely to negotiate as favorable a bargain on resale to another purchaser.

Tax deductions are offered to encourage investment in securities with either a relatively low early rate of return or a high risk factor. But by virtue of the rescission, it is now the seller who has assumed the risks associated with the particular investment. If the well proves dry, it will not be the original purchaser who suffers but the original seller. Similarly, it is no longer the purchaser's money that is being tied down by the investment, but the seller's money. If the investment is capital-intensive in its early stages with a promise of later return, it is the seller who bears the cost of the deferral of gain. Therefore, the seller should have the benefit of the deferral of tax.

It might be objected that the seller may resell shortly after taking the deductions. But of course if he does so, he will once again be taxed on the sale and at least a portion of the deductions will promptly be recaptured by the Government. This result follows because the seller, if he is awarded tax deductions in the year of rescission, has a lower adjusted basis in the security.

\section{Conclusion}

If the seller of a tax shelter security is forced to rescind, and his purchaser has earned substantial tax benefits on the security, the seller has a strong private law claim to recover those tax benefits as profits. But as a public law matter, the court ordering rescission 
should not preempt the Government's claim to recaputre the tax benefits. If the Government treats the rescission as a nullification of the original transaction, it will recover the purchaser's tax benefit through application of the tax benefit rule. Under this approach, the seller's capital gain on the initial transaction will be restored to him, and he will take the security back at his original cost basis. Moreover, since this approach "eliminates" the purchaser's tax benefits, a court ordering rescission has no grounds for awarding the seller an offset to his contractual liability.

If the Government instead treats the rescission as a separate transaction, the seller's capital gain on the initial transaction will stand and he will reassume ownership of the security at a higher cost basis. A court ordering rescission should then apply a simple formula to calculate an appropriate offset to be applied against the seller's liability for the repurchase price. The resulting offset transfers to the seller that portion of the purchaser's tax benefit that the purchaser would otherwise retain and ensures that the purchaser is restored to the status quo ante.

Regardless of whether the Government uses a nullification approach or an independent transaction approach, a number of factors suggest that the most appropriate solution to the problem is to have the Internal Revenue Service award the seller a tax loss equivalent to that taken by the purchaser. The tax loss awarded to the seller would equal the total amount of deductions taken by the purchaser during the years he held the security and would offset income of the seller in the year of rescission that would otherwise be taxed at current rates. Of course, if the Government chooses this solution, a court should not award the seller an offset to his contractual liability. The suggested solution recognizes the strong private law claim of the seller to restoration of the tax benefits taken by the purchaser, but properly places tax matters within the realm of public law. 